\title{
Diffusion of peroxides through dentine in vitro with and without prior use of a desensitizing varnish
}

\author{
Christian Hannig • Hans Christian Weinhold • \\ Klaus Becker • Thomas Attin
}

Received: 16 March 2010 / Accepted: 26 July 2010 /Published online: 10 August 2010

(C) Springer-Verlag 2010

\begin{abstract}
Different bleaching regimens are used in dentistry possibly penetrating the dentine and affecting the pulp. The aim of the present study was to investigate peroxide diffusion through dentine pre-treated with a desensitizing varnish (Vivasens ${ }^{\circledR}$ ) in a standardized in vitro setup during application of different bleaching materials. The penetration was tested using $1.3-\mathrm{mm}$-thick bovine dentine slabs. The following bleaching materials were tested with and without prior application of the desensitizing varnish on the external side of the dentine slabs: Vivastyle, Whitestrips, Simply White, Opalescence (external bleaching), and sodium perborate (internal bleaching, only tested without varnish; $n=8$ samples per subgroup). The penetration of peroxides was measured photometrically using 4-aminoantipyrin as a substrate, the penetration of peroxides was monitored over
\end{abstract}

\section{Hannig $(\triangle)$}

Clinic of Conservative Dentistry, Faculty of Medicine 'Carl

Gustav Carus', Technical University of Dresden,

01307 Dresden, Fetscherstr. 74,

Germany

e-mail: christian.hannig@uniklinikum-dresden.de

H. C. Weinhold

Dental practice,

Postboks 143, Arbeidergata 28,

3051 Mjøndalen, Norway

H. C. Weinhold

Department of Operative Dentistry, Preventive Dentistry

and Periodontology, University of Göttingen,

Robert-Koch-Str. 40,

37075 Goettingen, Germany

\section{K. Becker $\cdot$ T. Attin}

Clinic for Preventive Dentistry, Periodontology and Cariology, University of Zürich,

Plattenstr. 11,

8032 Zürich, Switzerland
240 min. All bleaching agents yielded a diffusion of peroxides through the dentine, the kinetics of penetration were approximately linear for all materials tested. The significantly highest diffusion of peroxides was observed with Opalescence, the lowest with sodium perborate. The adoption of the desensitizing varnish reduced the diffusion of peroxides significantly for all external bleaching materials. Peroxides penetrated the dentine during application of bleaching materials; the penetration of peroxides can be reduced by application of a desensitizing agent.

Keywords Peroxide $\cdot$ Peroxidase $\cdot$ Dentine $\cdot$ Pulp · Bleaching $\cdot$ Desensitizer

\section{Introduction}

External and internal bleaching regimens have been established as relevant and accepted methods in aesthetic dentistry $[1,2]$. However, peroxides may induce oxidative stress for the oral hard and soft tissues and side effects of peroxides are still a point of discussion in the literature [3, 4]. The antioxidative capacity in the oral cavity is limited due to the fact that peroxidase in the saliva and in the acquired pellicle as the most relevant antioxidative protein is inactivated irreversibly by its substrate $[5,6]$. This applies also for human peroxidase activity in the pulp chamber. Typical side effects of external bleaching are gum burning, gingival erosions, and tooth hypersensitivities $[1,4,7,8]$. Furthermore, alterations of restorative materials and dental hard tissues are discussed controversially in the literature [9-12]. In this context, it has to be taken in consideration that oral soft tissues undergo a very fast turnover whereas dental hard tissues are nonregenerating structures with non-shedding surfaces. Though some of the side effects might be transient, numerous people 
claim hypersensitivities during application of the external bleaching agents that might lead to cessation of the regimen $[1,4,7]$. This applies especially for patients suffering from exposed root surfaces. The dentine is of much higher permeability as compared with the enamel though also the latter is permeable for hydrogen peroxide [13, 14]. The considerable diffusion of peroxides through the exposed dentine into the pulp chamber recorded in several studies is regarded as main cause for this effect $[1,14,15]$. Hydrogen peroxide inhibits pulpal enzymes[16]. Succinyldehydrogenase is inhibited by peroxides as observed in cell cultures [13]. As a result of peroxide diffusion transient inflammation of the pulp has been observed histologically $[17,18]$. Also the composition of the bleaching agent and its viscosity have an impact on the release and diffusion of the hydrogen peroxide and therewith on the intensity of perceived side effects [19-22]. Due to this fact desensitizing varnishes are recommended for coating of root surfaces during application of bleaching agents [23]. However, it is not known, if these varnishes hamper penetration of peroxides through underlying dentine efficiently.

Thus, the aim of the present in vitro study was to investigate and to quantify the penetration of typical and representative bleaching materials [24] through dentine in a standardized setup. Thereby, the effect of a desensitizing varnish based on methacrylates on peroxide diffusion was tested. Sodium perborate typically adopted for internal bleaching was included in the study as a reference.

\section{Methods}

\section{Dentine specimens}

Dentine specimens were gained from bovine incisors. The dentine slabs were ground plane parallel till grain size 4000 , the diameter of the samples was at least $8 \mathrm{~mm}$, and the thickness amounted exactly to $1.3 \mathrm{~mm}$. The smear layer was removed by rinsing with EDTA (5\%) and aqua bidest. for $10 \mathrm{~s}$ each. Before the experiments, the samples were stored in aqua bidest. for $24 \mathrm{~h}$. Plastic rings (polypropylene, diameter $8 \mathrm{~mm}$ ) were fixed with wax on both sides of the dentine slabs using a template for exact positioning (Fig. 1).

Application of the bleaching agents

The external bleaching agents were placed on the former enamel site of the dentine specimens. If testing Whitestrips $^{\circledR}$, a piece of the strip (diameter $8 \mathrm{~mm}$ ) was placed on the dentine slabs, for application of Opalescence ${ }^{\circledR} \mathrm{Xtra}^{\circledR}$ Boost $^{\mathrm{TM}}$ or VivaStyle ${ }^{\circledR}$ a volume of $50 \mu \mathrm{l}$ gel was filled in the ring. Simply White ${ }^{\circledR}$ was brushed on the dentine surface with the paint brush included in the kit. Sodium

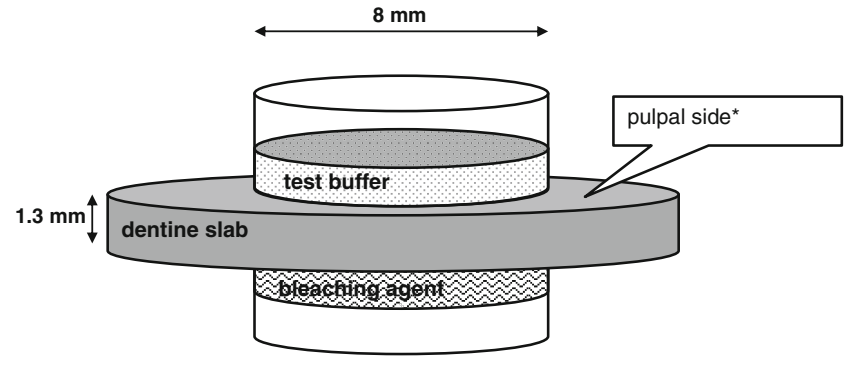

Fig. 1 Setup of the in vitro experiments, * sodium perborate was applicated on the pulpal side

perborate was mixed with aqua bidest. $(1 \mathrm{~g}$ and $750 \mu \mathrm{l}$ aqua bidest.), $50 \mu \mathrm{l}$ were adopted in the experiment. In contrast to the external bleaching materials, sodium perborate was applied on the pulpal site of the dentine samples. Detailed information on the materials is given in Table 1. Due to the high viscosity of the bleaching agents they did not flew out of the ring. A volume of $100 \mu l$ phosphate buffer was pipetted into the ring on the upper side (Fig. 1). Peroxide diffusion was assessed $10 \mathrm{~s}$ after application of the bleaching agent as well as after 30,60, 90, 120, 150, 180, and $240 \mathrm{~min}$. At each time point, the buffer was completely removed, transferred into the well of a microtiter plate and replaced by fresh buffer solution. Incubation with the bleaching agents was carried out in a wet chamber at $37^{\circ} \mathrm{C}$.

\section{Sealant}

The following desensitizing agent was tested with the external bleaching materials: Vivasens ${ }^{\circledR}$, Free Stand $^{\circledR}$ single dose $(0.1 \mathrm{~g})$, Ivoclar Vivadent AG, Schaan, Liechtenstein, LOT: G20436; composition: ethanol, water, hydroxypropylcellulose, polyethyleneglycol, dimethacrylate, and other methacrylates (Table 2).

The desensitizing varnish was adopted according to manufacturer's instructions. One single dose stand was used for two specimens. Dry dentine surfaces were sealed with a thin homogenous layer of the varnish for $10 \mathrm{~s}$, and then dried with oil free air for $10 \mathrm{~s}$. Before application of the bleaching agents the coated samples were stored in a wet chamber for $10 \mathrm{~min}$ at $37^{\circ} \mathrm{C}$.

\section{Peroxide assay}

Peroxide diffusion was measured photometrically using 4aminoantipyrin as a substrate as described previously [19, 25-28]. Peroxidase catalyzes the reaction of 4aminoantipyrin and phenol with hydrogen peroxide. Inorganic peroxides are oxidized by peroxidase (oxidoreduktase EC1.11.1.7). Thereby oxygen is released subsequently oxidizing the achromatic chromogenic hydrogen donor. The product chinonimin has its maximum of extinction at a 
Table 1 Bleaching agents tested in the study

\begin{tabular}{|c|c|c|c|c|c|}
\hline & \multicolumn{5}{|l|}{ Bleaching agent } \\
\hline & $\begin{array}{l}\text { Clinical } \\
\text { application }\end{array}$ & Composition & $\mathrm{pH}$ & Lot no. & Manufacturer \\
\hline VivaStyle $^{\circledR}$ & $\begin{array}{l}\text { Individual } \\
\text { tray (home } \\
\text { bleaching) }\end{array}$ & $\begin{array}{l}\text { Carbamide peroxide } 10 \% \text {, glycerine, } \\
\text { buffered polycarbonic acid }\end{array}$ & 6.6 & GL1029 & $\begin{array}{l}\text { Ivoclar Vivadent AG, } \\
\text { Schaan, Liechtenstein }\end{array}$ \\
\hline Whitestrips $^{\circledR}$ & $\begin{array}{l}\text { Polyethylene strips } \\
\text { (home bleaching) }\end{array}$ & $\begin{array}{l}\text { Water, glycerine, } \mathrm{H}_{2} \mathrm{O}_{2} 6,5 \% \text {, saccharin, } \\
\text { Carbopol } 956 \text {, sodium hydroxide, acidic } \\
\text { sodium pyrophosphate, sodium stannate }\end{array}$ & 6.4 & $5146 \mathrm{BT} 2 \mathrm{C}$ & $\begin{array}{l}\text { Procter \& Gamble } \\
\text { Technical Centers Ltd., } \\
\text { Egham, UK }\end{array}$ \\
\hline $\begin{array}{l}\text { Opalescence }^{\circledR} \\
\text { Boost }^{\text {TM }}\end{array}$ & In office & $\begin{array}{l}\mathrm{H}_{2} \mathrm{O}_{2} 38 \% \text {, carotine, water, glycerine, } \\
\text { thickening agent }\end{array}$ & 7.3 & ВØВYV & $\begin{array}{l}\text { UP Dental GmbH, Köln, } \\
\text { Germany }\end{array}$ \\
\hline Simply White ${ }^{\circledR}$ & $\begin{array}{l}\text { Paint on } \\
\text { (home bleaching) }\end{array}$ & $\begin{array}{l}\text { Ethanol, water, PEG-2 M, PEG-12, } 5.9 \% \\
\mathrm{H}_{2} \mathrm{O}_{2} \text {, glycerine, carbomere, sodium } \\
\text { phosphate, phosphoric acid, BHT }\end{array}$ & 8.9 & $\begin{array}{l}\text { 3344AM } \\
5068 \mathrm{AM}\end{array}$ & $\begin{array}{l}\text { Colgate-Palmolive, } \\
\text { Hamburg, Germany }\end{array}$ \\
\hline Sodium perborate & Internal bleaching & $\begin{array}{l}\text { Sodium perborate-(trihydrate), chloride, } \\
\text { sulfate, iron }\end{array}$ & 10.2 & 22349512 & $\begin{array}{l}\text { Caesar \& Lorentz, } \\
\text { Hilden, Germany }\end{array}$ \\
\hline
\end{tabular}

wavelength of $510 \mathrm{~nm}$. For determination of peroxides a calibration curve was carried out with different peroxide concentrations. The composition of the reaction buffer was 4-aminoantipyrin $(4 \mathrm{mmol} / \mathrm{l})$, peroxidase $(0.4 \mathrm{U} / \mathrm{ml})$, and phenol $(24 \mathrm{mmol} / \mathrm{l})$ in 0.1 molar phosphate buffer $(\mathrm{pH} 7.0)$ [25]. A volume of $100 \mu \mathrm{l}$ reaction buffer was added to $100 \mu$ sample from the dentine specimen and the absorption was read vs. $0.1 \mathrm{M}$ phosphate buffer. If necessary, samples were diluted 1:20 with phosphate buffer. Peroxide diffusion was assessed $10 \mathrm{~s}$ after application of the bleaching agent and after 30,60,90,120, 150, 180, and $240 \mathrm{~min}$.

Statistics

Statistical evaluation was carried out by ANOVA followed by the Scheffé-procedure using SPSS 16.0 (SPSS Inc, Chicago, IL, USA). The level of significance was $p \leq 0.05$. For pairwise comparison of the external bleaching agents with and without the varnish the Mann-Whitney test was adopted.

\section{Results}

The kinetics of peroxide diffusion were approximately linear for all bleaching agents tested as depicted exemplarily for Whitestrips (Fig. 2).

Irrespective of the desensitizing agent, significantly different amounts of peroxides penetrated the dentine samples when adopting the different materials. The cumulated diffusion of peroxides was balanced after 60 and $240 \mathrm{~min}$, respectively.

For the unsealed specimens, the bleaching material had significant impact on the amount of peroxides detected on the pulpal side (ANOVA, $p<0.001$ ). The Scheffé-procedure indicated that Opalescence yielded the significantly highest diffusion of peroxides as compared with the other materials

Table 2 Cumulated peroxide diffusion through the dentine slabs during application of the different bleaching agents with and without desensitizing varnish (Vivasens) after 60 and $240 \mathrm{~min}$

\begin{tabular}{|c|c|c|c|c|c|}
\hline & Whitestrips ${ }^{\circledR}$ & VivaStyle ${ }^{\mathbb{R}}$ & Simply White ${ }^{\circledR}$ & Opalescence ${ }^{\circledR}$ & Sodium perborate \\
\hline \multicolumn{6}{|c|}{ Cumulated peroxide diffusion over $60 \mathrm{~min}$ [nmol] } \\
\hline Without desensitzing agent & $5.3 \pm 5.8$ & $1.1 \pm 1.9$ & $26.4 \pm 35.4$ & $1,603 \pm 1,022$ & $0.0 \pm 0.0$ \\
\hline With desensitizing varnish (Vivasens) & $1.4 \pm 2.1$ & $0.3 \pm 0.3$ & $0.6 \pm 0.7$ & $41.1 \pm 28.3$ & \\
\hline$\%$ reduction & $-74 \%$ & $-73 \%$ & $-98 \%$ & $-97 \%$ & \\
\hline \multicolumn{6}{|c|}{ Cumulated peroxide diffusion over $240 \mathrm{~min}$ [nmol] } \\
\hline Without desensitizing agent & $103 \pm 62.3$ & $158 \pm 179$ & $491 \pm 314$ & $8,021 \pm 3,007$ & $3.7 \pm 2.9$ \\
\hline With desensitizing varnish (Vivasens) & $22.8 \pm 20.8$ & $5.2 \pm 2.8$ & $5.3 \pm 1.8$ & $221.7 \pm 89.2$ & \\
\hline$\%$ reduction & $-78 \%$ & $-97 \%$ & $-99 \%$ & $-97 \%$ & \\
\hline
\end{tabular}

$\mathrm{MV} \pm \mathrm{SD}, n=8$ samples/subgroup 


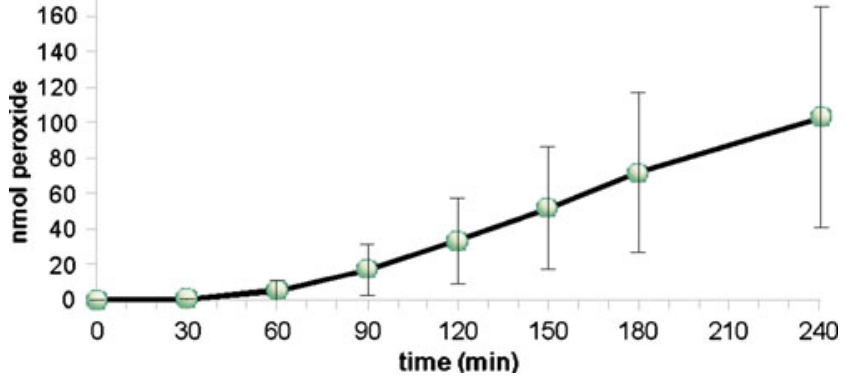

Fig. 2 Kinetics of peroxide diffusion, application of Whitestrips over $4 \mathrm{~h}$, the amount of peroxides was cumulated. $\mathrm{MV} \pm \mathrm{SD}, n=8$ samples, no desensitizing agent was adopted

$(p<0.001)$. This applied for the cumulated 60 min data as well as for the $240 \mathrm{~min}$ values.

Only the materials for external bleaching were tested after sealing with desensitizing varnish. Also with this coating, the bleaching material still had significant impact on the amount of peroxides detected on the pulpal side after 60 and $240 \mathrm{~min}$ (ANOVA, $p<0.001$ ). Opalescence yielded the significantly highest diffusion of peroxides as compared with the other materials (Scheffé procedure, $p<0.001$ ).

The application of Viavsens led to a significat reduction of peroxide diffusion for all external bleaching materials after 60 as well as after $240 \min (p<0.05$, Mann-Whitney test). The most pronounced effects were observed for Simply white.

\section{Discussion}

Peroxide diffusion through dentine has been observed in the present study. As in previous studies on bioadhesion, bovine dentine specimens were used for the purpose of standardization [29-33]. The physico-chemical characteristics do not differ considerably from human dentine [34]. Typically, the diameter of the tubules in bovine dentine is 3-5 $\mu \mathrm{m}$ with 20,000 tubules $/ \mathrm{mm}^{2}$ as measured microscopically in our laboratory [35], in human dentine in the outer layers near the enamel $0.5-1.2 \mu \mathrm{m}$ have been recorded for the mean diameter with $10,000-25,000$ tubules $/ \mathrm{mm}^{2}$ [36]. This has to be considered when interpreting the observed peroxide diffusion. The adopted assay for quantification of the diffused peroxides has been used previously for precise measurement of peroxides in the oral cavity during application of bleaching regimen. It is not impaired by salivary components $[25,37]$.

For direct comparison all bleaching materials were adopted for the same time though different periods of application are common. This has to be taken into account when estimating the peroxide diffusion occurring clinically. A pure in vitro setup has been chosen. In the oral cavity, peroxide catabolism and peroxide diffusion would be modulated by the saliva and the acquired pellicle $[5,6]$. The antioxidative potential in the oral cavity is limited due to the fact that peroxidase in the saliva and in the acquired pellicle is inactivated by its substrate hydrogen peroxide [5, 6]. Accordingly, the protective properties of the pellicle are limited during application of bleaching agents [6]. The observed penetration of peroxides through the dentine is in good accordance with several previous studies [13, 17, 21, 22]. The distinctly highest peroxide diffusion was recorded for Opalescence with a peroxide concentration of $38 \%$ and a very high viscosity of the bleaching gel. Free $\mathrm{H}_{2} \mathrm{O}_{2}$ penetrates dentine to a significantly greater extent as compared with peroxides released from carbamide peroxide [21]. Opalescence and Simply White contain pure $\mathrm{H}_{2} \mathrm{O}_{2}$. Furthermore, bleaching agents of high viscosity yield a more pronounced peroxide diffusion than low viscous ones [20]. This corresponds well with the observed peroxide diffusion which was most pronounced for the high viscous Opalescence and the likewise viscous Simply White. Significantly lower diffusion was measured for Vivastyle and Whitestrips. However, the extent of peroxide diffusion was described to be not correlated with the concentration of the adopted bleaching agent [21]. In contrast to this previous finding, the highest peroxide release was observed in the present study with Opalescence featuring also the highest peroxide concentration.

Sodium perborate typically adopted for internal bleaching was also included in the study and yielded the significantly lowest peroxide diffusion. Sodium perborate mixed with tap water can be regarded as a low drug release compound [38]. Due to this fact, peroxide contamination of the periodontal structures seems to be rather low and antioxidative enzymes are assumed to be able to compensate for the oxidative stress. If sodium perborate was prepared with hydrogen peroxide instead of water a more pronounced diffusion of peroxide would have been expected. Adverse effects of internal bleaching have been recorded especially if sodium perborate was used together with $\mathrm{H}_{2} \mathrm{O}_{2}$ for internal bleaching [39-41].

Anyhow, if balancing the peroxide release into the periodontal structures during internal bleaching, the application over up to 1 week has to be taken into consideration.

Peroxides are considered to be the key factor inducing tooth hypersensitivity. Apparently, the adopted sealant prevented peroxide diffusion significantly. Probably, the organic and apolar components of the material formed a layer and barrier against the extensive penetration of peroxides. It has been shown in a clinical study that Vivasens and other desensitizing agents are effective in alleviating dentine hypersensitivity. However, peroxides as a stimulus were not tested [42]. In a previous clinical study, the degree of hypersensitivities and the number of subjects with hypersensitivities were lower if Vivasens was adopted, 
though the difference was not significant as compared with controls [23]. The reduced peroxide diffusion through the dentine as recorded in the present study might reduce the efficacy of the bleaching agent. However, a previous clinical study indicated that Vivasens had no negative effect on the whitening effect of bleaching agents [23]. This was also shown in an in vitro simulation [43]. Additionally, Vivasens is able to reduce dentin dehydration during bleaching, which is also supposed to contribute to bleaching-induced hypersensitivities [44].

From a toxicological point of view and for prevention of side effects, Vivasens in combination with low-dose homebleaching systems adopted with individual splints or polyethylene foils seemed recommendable.

\section{Conclusions}

- Peroxide diffusion through dentine depends on composition and concentration of the bleaching agent used.

- Application of a desensitizing agent significantly reduces peroxide penetration through dentine.

Acknowledgment The bleaching materials and the desensitizer were kindly supplied by Ivoclar Vivadent.

Conflict of Interest The authors declare that they have no conflict of interest.

\section{References}

1. Burrows S (2009) A review of the safety of tooth bleaching. Dent Update 36:604-606, 608-610, 612-604

2. Burrows S (2009) A review of the efficacy of tooth bleaching. Dent Update 36:537-538, 541-534, 547-538 passim

3. Floyd RA (1997) The effect of peroxides and free radicals on body tissues. J Am Dent Assoc 128(Suppl):37S-40S

4. Nathanson D (1997) Vital tooth bleaching: sensitivity and pulpal considerations. J Am Dent Assoc 128(Suppl):41S-44S

5. Battino M, Ferreiro MS, Gallardo I, Newman HN, Bullon $P$ (2002) The antioxidant capacity of saliva. J Clin Periodontol 29:189-194

6. Hannig C, Spitzmuller B, Knausenberger S, Hoth-Hannig W, Hellwig E, Hannig M (2008) Detection and activity of peroxidase in the in situ formed enamel pellicle. Arch Oral Biol 53:849-858

7. Powell LV, Bales DJ (1991) Tooth bleaching: its effect on oral tissues. J Am Dent Assoc 122:50-54

8. Haywood VB, Leonard RH, Nelson CF, Brunson WD (1994) Effectiveness, side effects and long-term status of nightguard vital bleaching. J Am Dent Assoc 125:1219-1226

9. Attin T, Vollmer D, Wiegand A, Attin R, Betke H (2005) Subsurface microhardness of enamel and dentin after different external bleaching procedures. Am J Dent 18:8-12

10. Attin T, Hannig C, Wiegand A, Attin R (2004) Effect of bleaching on restorative materials and restorations - a systematic review. Dent Mater 20:852-861
11. Potocnik I, Kosec L, Gaspersic D (2000) Effect of 10\% carbamide peroxide bleaching gel on enamel microhardness, microstructure, and mineral content. J Endod 26:203-206

12. Hegedus C, Bistey T, Flora-Nagy E, Keszthelyi G, Jenei A (1999) An atomic force microscopy study on the effect of bleaching agents on enamel surface. J Dent 27:509-515

13. Hanks CT, Fat JC, Wataha JC, Corcoran JF (1993) Cytotoxicity and dentin permeability of carbamide peroxide and hydrogen peroxide vital bleaching materials, in vitro. J Dent Res 72: 931-938

14. Joiner A (2006) The bleaching of teeth: a review of the literature. J Dent 34:412-419

15. Trindade FZ, Ribeiro AP, Sacono NT, Oliveira CF, Lessa FC, Hebling J, Costa CA (2009) Trans-enamel and trans-dentinal cytotoxic effects of a $35 \% \mathrm{H} 2 \mathrm{O} 2$ bleaching gel on cultured odontoblast cell lines after consecutive applications. Int Endod J 42:516-524

16. Bowles WH, Thompson LR (1986) Vital bleaching: the effects of heat and hydrogen peroxide on pulpal enzymes. J Endod 12: $108-112$

17. Kwong K, Mohammed S, McMillan MD, Stokes AN (1993) Evaluation of a 10 percent carbamide peroxide gel vital bleaching agent. N Z Dent J 89:18-22

18. Leonard RH Jr, Haywood VB, Phillips C (1997) Risk factors for developing tooth sensitivity and gingival irritation associated with nightguard vital bleaching. Quintessence Int 28:527-534

19. Hannig C, Zech R, Henze E, Dreier S, Attin T (2005) Peroxide release into saliva from five different home bleaching systems in vivo. Am J Dent 18:13-18

20. Thitinanthapan W, Satamanont P, Vongsavan N (1999) In vitro penetration of the pulp chamber by three brands of carbamide peroxide. J Esthet Dent 11:259-264

21. Cooper JS, Bokmeyer TJ, Bowles WH (1992) Penetration of the pulp chamber by carbamide peroxide bleaching agents. J Endod 18:315-317

22. Bowles WH, Ugwuneri Z (1987) Pulp chamber penetration by hydrogen peroxide following vital bleaching procedures. J Endod 13:375-377

23. Ziebolz D, Hannig C, Attin T (2008) Influence of a desensitizing agent on efficacy of a paint-on bleaching agent. Am J Dent 21:77-82

24. Hannig C, Duong S, Becker K, Brunner E, Kahler E, Attin T (2007) Effect of bleaching on subsurface micro-hardness of composite and a polyacid modified composite. Dent Mater 23:198-203

25. Hannig C, Zech R, Henze E, Dorr-Tolui R, Attin T (2003) Determination of peroxides in saliva - kinetics of peroxide release into saliva during home-bleaching with Whitestrips and Vivastyle. Arch Oral Biol 48:559-566

26. Bauminger BB (1974) Micro method for manual analysis of true glucose in plasma without deproteinization. J Clin Pathol 27:1015-1017

27. Trinder P (1969) Determination of blood glucose using 4-amino phenazone as oxygen acceptor. J Clin Pathol 22:246

28. Trinder P (1969) Determination of blood glucose using an oxidase-peroxidase system with a non-carcinogenic chromogen. J Clin Pathol 22:158-161

29. Hannig C, Hoch J, Becker K, Hannig M, Attin T (2005) Lysozyme activity in the initially formed in situ pellicle. Arch Oral Biol 50:821-828

30. Hannig C, Attin T, Hannig M, Henze E, Brinkmann K, Zech R (2004) Immobilisation and activity of human alpha-amylase in the acquired enamel pellicle. Arch Oral Biol 49:469-475

31. Hannig M, Fiebiger M, Guntzer M, Dobert A, Zimehl R, Nekrashevych Y (2004) Protective effect of the in situ formed short-term salivary pellicle. Arch Oral Biol 49:903-910

32. Nakamichi I, Iwaku M, Fusayama T (1983) Bovine teeth as possible substitutes in the adhesion test. J Dent Res 62:1076-1081 
33. Hannig C, Becker K, Hausler N, Hoth-Hannig W, Attin T, Hannig M (2007) Protective effect of the in situ pellicle on dentin erosion - an ex vivo pilot study. Arch Oral Biol 52:444-449

34. TJ EM, Marx R (1998) Materialkennwerte der Zahnhartsubstanz des Rindes im Vergleich zur humanen Zahnhartsubstanz. Dtsch Zahnärztl Z 53:713-717

35. Jung DJ, Al-Ahmad A, Follo M, Spitzmüller B, H-H W, Hannig M, Hannig C (2010) Visualization of initial bacterial colonization on dentine and enamel in situ. J Microbiol Meth 81:166-174

36. Garberoglio R, Brannstrom M (1976) Scanning electron microscopic investigation of human dentinal tubules. Arch Oral Biol 21:355-362

37. Hannig C, Willenbücher S, Becker K, Mahony C, Attin T (2006) Recovery of peroxides in saliva during home bleaching-influence of smoking. J Oral Rehabil 33:533-541

38. Attin T, Paque F, Ajam F, Lennon AM (2003) Review of the current status of tooth whitening with the walking bleach technique. Int Endod J 36:313-329
39. Weiger R, Kuhn A, Lost C (1994) Radicular penetration of hydrogen peroxide during intra-coronal bleaching with various forms of sodium perborate. Int Endod J 27:313-317

40. Rotstein I, Friedman S, Mor C, Katznelson J, Sommer M, Bab I (1991) Histological characterization of bleaching-induced external root resorption in dogs. J Endod 17:436-441

41. Friedman S, Rotstein I, Libfeld H, Stabholz A, Heling I (1988) Incidence of external root resorption and esthetic results in 58 bleached pulpless teeth. Endod Dent Traumatol 4:23-26

42. Pamir T, Dalgar H, Onal B (2007) Clinical evaluation of three desensitizing agents in relieving dentin hypersensitivity. Oper Dent 32:544-548

43. Betke H, Revas P, Werner C, Attin T (2005) Einfluss von Desensibilisierungslacken auf die Zahnaufhellung in der Bleichtherapie. Quintessenz 56:589-597

44. Betke H, Kahler E, Reitz A, Hartmann G, Lennon A, Attin T (2006) Influence of bleaching agents and desensitizing varnishes on the water content of dentin. Oper Dent 31:536-542 